\title{
Determining a threshold measurement of Endometrial Thickness for Asymptomatic Postmenopausal Women: A single-centre case series
}

\author{
Amy Stewart ${ }^{1}$, Gurjot Gill ${ }^{2}$, Emma Readman ${ }^{3}$, Sonia Grover ${ }^{3}$, and Samantha Mooney ${ }^{3}$ \\ ${ }^{1}$ Peninsula Health \\ ${ }^{2}$ The University of Melbourne \\ ${ }^{3}$ Mercy Hospital for Women
}

November 4, 2021

\begin{abstract}
Objective: To determine the endometrial thickness at which endometrial sampling is indicated in asymptomatic post-menopausal women referred with thickened endometrium on ultrasound. Design: Retrospective case series Setting: Mercy Hospital for Women, Melbourne Population: Post-menopausal women without bleeding, undergoing hysteroscopy for thickened endometrium Methods: Logistic regression was used to examine the association between a range of variables and pre-malignant or malignant pathology and endometrial thickness Main outcome measures: The primary outcome was endometrial malignancy/premalignancy and its relation to endometrial thickness. Secondary outcomes focused on identifying additional predictors which may influence endometrial malignancy such as ultrasound findings, years since menopause, age, obesity, diabetes, and tamoxifen use. Results: A total of 404 postmenopausal women met the inclusion criteria for this study. The mean (SD) age of patients at presentation was 65 (9.09) years and the mean BMI was $29.86 \mathrm{~kg} / \mathrm{m} 2(6.52)$. Of these women, nine (2.2\%) were diagnosed with endometrial carcinoma and $7(1.7 \%)$ had endometrial hyperplasia with atypia. The most common histopathological finding was of a benign endometrial polyp $(153,37.9 \%)$. When including hyperplasia with or without atypia in histopathology of interest, a cut-off of [?] $9 \mathrm{~mm}$ provides the greatest sensitivity $(83.3 \%)$ and specificity (63.8\%) for a diagnosis of pre-malignant or malignant pathology (classification accuracy of $64.8 \%$; AUROC: 0.7358, 95\%CI: 0.6439, 0.8278) in this cohort. Conclusions: Using an endometrial thickness of [?] $9 \mathrm{~mm}$ can be safely used as a cut-off for endometrial sampling in post-menopausal women without bleeding. Funding: Norman Beischer Medical Research Foundation, 2018 NBMRF Grant Keywords: Endometrial thickness, Post-menopausal, endometrial hyperplasia
\end{abstract}

\section{Hosted file}

FINAL - BJOG Thickened ET Manuscript.docx available at https://authorea.com/users/444524/ articles/544220-determining-a-threshold-measurement-of-endometrial-thickness-forasymptomatic-postmenopausal-women-a-single-centre-case-series

\section{Hosted file}

Figure 1.docx available at https://authorea.com/users/444524/articles/544220-determining-athreshold-measurement-of-endometrial-thickness-for-asymptomatic-postmenopausal-women-asingle-centre-case-series

\section{Hosted file}

FINAL - Tables and Figures.docx available at https://authorea.com/users/444524/articles/ 544220-determining-a-threshold-measurement-of-endometrial-thickness-for-asymptomaticpostmenopausal-women-a-single-centre-case-series 


\section{Hosted file}

Table 1.docx available at https://authorea.com/users/444524/articles/544220-determining-athreshold-measurement-of-endometrial-thickness-for-asymptomatic-postmenopausal-women-asingle-centre-case-series

\section{Hosted file}

Table_2.docx available at https://authorea.com/users/444524/articles/544220-determining-athreshold-measurement-of-endometrial-thickness-for-asymptomatic-postmenopausal-women-asingle-centre-case-series 